\title{
Studi Kasus Website Gramedia sebagai Media Online untuk Membeli Buku
}

\author{
Ryan Pratama Sutanto \\ Program Studi Desain Komunikasi Visual, Fakultas Seni dan Desain, \\ Universitas Kristen Petra Surabaya, Indonesia \\ Email: ryan@petra.ac.id
}

\begin{abstract}
Abstrak
Perkembangan teknologi, diiringi dengan perkembangan kondisi/sosial manusia. Menilik perkembangan gadget dan smartphone, media buku berkembang selaras dengan perkembangan teknologi. Dulu, buku hanya dinikmati secara fisik. Kini, penikmat buku dapat juga menikmati buku melalui perangkatnya. Toko buku tak lagi hidup secara fisik melainkan didesain untuk berdiri dan berkembang di dunia virtual. Teknologi internet ini memungkinkan desain toko buku online dibuat. Website berjenis e-commerce ini adalah sebuah ranah bisnis yang baru berkembang pesat di Indonesia. Toko Buku Gramedia, adalah salah satu brand toko buku ternama di Indonesia. Website Toko Buku Gramedia menyediakan fitur bagi pengunjung website untuk membeli online. Menarik untuk dikaji, bahwa sebagai sebuah brand toko buku besar, Gramedia; sebagai pelopor brand toko buku lokal yang mengadopsi transaksi penjualan buku secara online.
\end{abstract}

Kata kunci: User interface, user experience, website.

\begin{abstract}
Technology development has greatly affected human life. Nowadays, gagdet such as smartphones evolve and impact traditional (physical) media like books. Now, we can access and read book with smartphone. The development of media, encourage book store to evolve using internet based media, such as website. This kind of website was called e-commerce website. In Indonesia, e-commerce has become very dominant media for Indonesians. Gramedia Book Store is one of Indonesia leading book store. Recently they launched a website for the users to buy books. This paper studies about how user using Gramedia Website.
\end{abstract}

Keywords: User interface, user experience, website.

\section{Pendahuluan}

Jaman modern membuat manusia berkembang dengan cepat dan menggunakan teknologi. Semakin berkembang teknologi yang ada, maka semakin berbeda pula perlakuan manusia terhadap kebutuhannya masing-masing. Manusia bersaing ketat untuk mengembangkan dirinya, maka manusia membutuhkan ilmu pengetahuan untuk terus berkembang dan belajar. Salah satu cara manusia memenuhi kebutuhannya ini adalah melalui buku untuk dibaca dan dipelajari. Oleh karena itu kehadiran toko buku adalah suatu hal yang tidak bisa dielakkan lagi.

Namun melihat pertumbuhan manusia yang pesat yang juga membutuhkan lahan yang cukup besar, di mana keberadaan toko buku pun artinya membutuhkan lahan yang juga cukup besar untuk bisa berdiri dan menjadi bagian dari perkembangan manusia. Dengan adanya perkembangan teknologi yang maju, lahan bukan lagi menjadi masalah bagi keberadaan sebuah toko buku.
Menilik perkembangan gadget dan smartphone, media buku berkembang selaras dengan perkembangan teknologi. Dulu, buku hanya dinikmati secara fisik. Kini, penikmat buku dapat juga menikmati buku melalui perangkatnya. Pada zaman yang serba bergantung dengan teknologi ini, manusia memiliki cara pandang yang berbeda terhadap keberadaan buku. Manusia berusaha menjawab keberadaan buku ini dengan mendesain cara yang memudahkan manusia dalam memenuhi kebutuhannya ini. Kemudahan teknologi memunculkan konsep-konsep baru yang dibentangkan di otak penikmat toko-toko buku tersebut. Toko buku tak lagi hidup secara fisik melainkan didesain untuk berdiri dan berkembang di dunia virtual. Teknologi internet ini memungkinkan desain toko buku online dibuat.

Proses pemilikan buku saat ini sudah tidak lagi hanya di lakukan secara konvensional. Fenomena ini menjadi suatu hal yang mengubah pandangan dan hubungan intim manusia dengan buku serta lingkungan pendukungnya karena perkembangan 
teknologi. Fenomena ini jelas mengubah pandangan dan perilaku konsumsi manusia terhadap buku serta lingkungan pendukungnya.

Website berjenis e-commerce ini adalah sebuah ranah bisnis yang baru berkembang pesat di Indonesia. E-commerce adalah metode komunikasi baru yang secara sederhana, cepat, murah, di mana penjual dan pembeli bisa melakukan transaksi. Toko Buku Gramedia, adalah salah satu brand toko buku ternama di Indonesia. Website Toko Buku Gramedia menyediakan fitur bagi pengunjung website untuk membeli online. Menarik untuk dikaji, bahwa sebagai sebuah brand toko buku besar, Gramedia; sebagai pelopor brand toko buku lokal yang mengadopsi transaksi penjualan buku secara online.

Melalui tulisan ini, diharapkan muncul desain toko buku online sejenis yang bisa mengadopsi dan teknologi berbasis internet dan web sebagai portal transaksi mereka.

\section{Metode Penelitian}

Pada tulisan ini, peneliti bertindak sebagai pengguna website Gramedia. Filosofi User-centered Design, berarti peneliti juga harus menjadi pengguna dan mencoba website secara langsung dan melakukan kegiatan (task) sebagai pengguna.

\section{Pemahaman Umum User-Centered Design}

Desain interface berbasis user (pengguna), dikenal sebagai user-centered design pertama kali dipopulerkan oleh Don Norman. User-centered design (UCD) kemudian berkembang pesat dan diaplikasikan tidak hanya dalam ranah desain produk saja.

UCD muncul dari Human Computer Interaction (HCI), sebuah desain metodologi bagi desainer dan developer. Secara esensial, UCD membantu mereka menciptakan aplikasi yang dapat memenuhi kebutuhan pengguna (Lowdermilk, 2013).

Proses UCD bekerja berlawanan dengan asumsi subyektif tentang perilaku pengguna. UCD membutuhkan bukti nyata yang membuktikan keputusan-keputusan desain yang dipilih adalah efektif (Lowdermilk, 2013).

Menggunakan UCD dalam desain interface akan memastikan bahwa desain aplikasi atau website akan memenuhi kebutuhan pengguna media Anda. Saat kebutuhan pengguna sebuah media website sudah terpenuhi maka secara otomatis pengguna tersebut akan merasakan pengalaman positif yang berkaitan dengan website itu. Pengalaman ini lah yang lazim disebut dengan user experience (UX).

Sebuah website dengan UX yang positif akan menimbulkan ketertarikan pengguna terhadap website dan memungkinkan mereka untuk kembali menggunakan website tersebut. Secara tidak langsung sebuah UX yang positif dan baik harus didukung dengan user interface (UI) yang baik. UI terbaik adalah sederhana dan intuitif, yaitu ketika pengguna bisa menemukan apa yang mereka cari dan menyelesaikan task (kegiatan) dengan kesalahan minimal dan efisien (Yayici, 2014).

\section{Toko Buku, Cara Konvensional dan Inovasi Teknologi}

Buku terus muncul dan bertahan dilihat dari begitu banyak buku yang diterbitkan dan kemunculan toko-toko buku yang merupakan saksi bertahannya keberadaan buku. Keberadaan toko buku saat ini pun dibilang relatif banyak dan bersaing ketat dalam menarik pelanggannya. Ada yang mengadakan diskon secara berkala, membuat sebuah acara untuk menarik massa datang dan membeli buku ke toko buku. Setiap toko buku tentu memiliki strategi tersendiri untuk menarik pengunjung ke tokonya. Toko buku terus berinovasi dalam setiap strategi yang dikeluarkannya. Toko buku berlomba-lomba membawa tokonya lebih mudah diakses, dalam artian dapat menembus ruang dan waktu. Dengan harapan lebih memudahkan pelanggan untuk membeli buku. Pemilik toko buku melakukannya dengan membuat toko buku mereka secara online melalui teknologi internet, yaitu website online.

Bila melihat kepadatan yang terjadi di toko buku secara berkala, maka tidak perlu menanyakan bagaimana toko buku membuat toko bukunya secara online. Dengan penuhnya toko, maka kenyamanan dalam pembelian pun dirasa sudah terganggu karena area yang kurang sebagai wadah untuk menampung para pelanggan. Rasa ini akan dirasakan oleh pelanggan sehingga memungkinkan dampak buruk bagi toko buku yang takut pelanggannya tidak lagi datang ke toko mereka. Menambah jumlah area bangunan, merupakan salah satu hal yang dirasa tidak mungkin, karena jumlah lahan pun sekarang sudah terbatas. Sehingga pada akhirnya, toko pun mencoba menyelesaikan permasalahan ini ke dalam media online; dengan menciptakan website online yang berfungsi sebagai media untuk jual beli.

Beberapa toko buku yang memiliki toko buku secara online, berusaha sebisa mungkin meng- 
gantikan peran manusia yang selalu melayani pelanggan di dalam toko dengan maksimal. Seperti pada pemenuhan judul buku berserta sinopsisnya juga sampai pada apakah stok buku tersebut masih ada atau tidak, kemudian keramahan saat dilayani di dalam toko yang digantikan oleh cara mengoperasikan situs online tersebut secara mudah. Hal-hal yang telah disebutkan, merupakan secuil pelayanan atau servis toko buku yang menjual bukunya secara online. Toko buku mengubah pandangan dan hubungan manusia saat berada di dalam toko buku secara nyata dengan berada di dalam toko buku secara online.

Toko Buku Gramedia, Online Store-User Interface

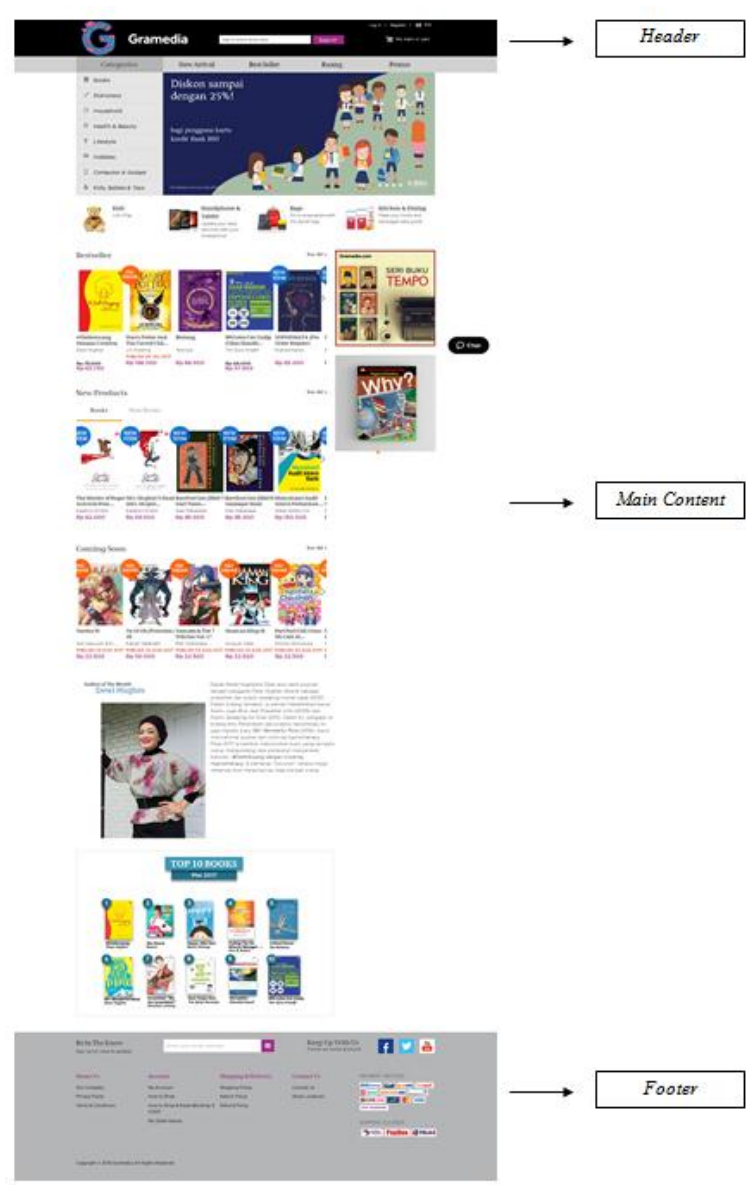

Gambar 1. Halaman utama website Gramedia

Gambar 1. menunjukkan tampilan halaman utama toko buku Gramedia secara online. Toko buku Gramedia secara online ini dilengkapi dengan database produk (buku, stationery, tas, tablet/handphone) secara detail. Hal ini memudahkan pengguna website untuk memilih dan mencari barang yang diinginkan. Secara umum, halaman utama dari website Toko Buku Gramedia ini dibagi menjadi 3 bagian besar: header, main content, dan footer (Gambar 1). Pada bagian header, terdapat beberapa elemen: logo Gramedia, search bar, login area, dan navigasi utama. Fitur search bar pada header, membuat pengguna website dengan mudah berselancar dan mencari judul buku yang diinginkan. Posisi navigasi utama yang berada pada $1 / 3$ atas layar monitor juga memudahkan pencarian buku.

Sebuah toko buku yang sudah cukup ternama yakni toko buku Gramedia. Toko buku Gramedia memiliki banyak sekali cabang hampir di setiap kota. Bahkan di setiap kotanya memiliki lebih dari 1 atau 2 gerai toko buku Gramedia. Pada beberapa kota, Gramedia membuka toko buku miliknya di dalam mall/pusat perbelanjaan. Namun, mengikuti arus kemajuan jaman Gramedia membuka fitur baru yakni belanja buku melalui internet. Toko buku online milik Gramedia bisa diakses melalui alamat situs: www.gramedia.com

Pada bagian main content, terdapat beberapa elemen: secondary navigation, best seller, new product, best author, top ten books. Elemen secondary navigation berada di sisi atas dari website Gramedia. Posisi ini memudahkan pengguna untuk berselancar dengan mencari buku-buku berdasarkan kategori yang dikehendaki.

Fitur browse dan search adalah salah satu fitur yang paling krusial dan diperlukan dalam sebuah website bertipe e-commerce seperti ini. Penempatan kedua fitur ini di sisi atas dari website sudah tepat. Penempatan ini memudahkan bagi pengguna untuk berselancar dan langsung mencari buku-buku yang akan mereka beli.

Pada bagian footer, terdapat beberapa elemen: sign up newsletter, third navigation, metode pembayaran, dan hak cipta. Bagian footer sering kali hanya berisi sedikit materi. Namun pada website Gramedia ini, memanfaatkan ruang footer dengan mengajak pengguna untuk berlangganan newsletter. Pengguna yang berlangganan maka secara otomatis akan mendapatkan info terbaru dari Gramedia.

\section{Toko Buku Gramedia, Online Store-User flow}

Untuk menciptakan UX yang hebat - desainer harus berfokus pada kebutuhan pengguna, itu berarti mengembangkan pemahaman tentang bagaimana menciptakan task flow (aliran kegiatan) terbaik untuk pengguna. Semakin baik Anda memfasilitasi user flow (alur pengguna) dari awal sampai akhir pada proses tertentu - semakin mudah produk Anda bekerja dan semakin besar kemungkinan Anda menghadirkan UX yang luar biasa. User flow juga adalah proses dari pengguna 
yang tiba di website untuk menyelesaikan kegiatan-kegiatan mereka mereka (Flow Design Processes-Focusing on the User's Needs, 2017). Oleh karena itu, sebuah information architecture (IA) website yang baik harus dibuat.

Secara umum, ketika seorang pengguna menggunakan sebuah website e-commerce, ada 3 hal tujuan utama yang bisa diduga, yaitu: pengguna ingin membeli produk (dalam hal ini buku), pengguna mencari alternatif buku, pengguna ingin melakukan retur barang. Dari ketiga hal tersebut, pembelian produk adalah yang paling sering dilakukan. Oleh karena itu desain website harus memudahkan pengguna melakukan pemesanan buku. Berdasarkan hasil pengamatan dan percobaan (tes) ke pengguna Website Gramedia memiliki user flow seperti ini:

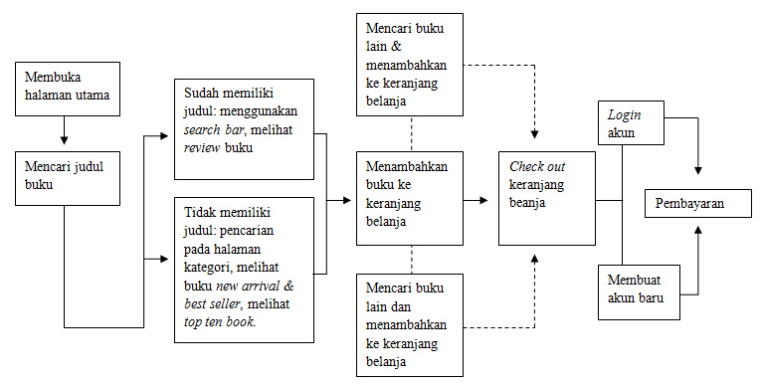

Gambar 2. Diagram User Flow

Berdasarkan gambar di atas, dapat dilihat bahwa user flow website Gramedia cukup linear, simple dan sederhana. User flow ini didukung dengan penempatan UI yang berorientasi pada kegiatan search dan browsing pada website Gramedia.

Beberapa elemen dan fitur dari situs Gramedia yang mendukung orientasi search and browsing bagi pengguna. Pertama, penempatan search bar pada header yang mencolok dan berada pada posisi atas-tengah memudahkan pengguna menggunakan fitur tersebut (gambar 3).

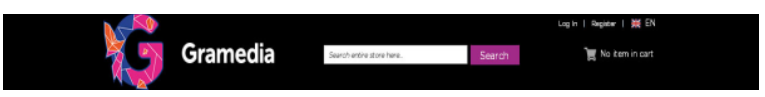

Gambar 3. Posisi search bar pada header

Kedua, penempatan menu utama dan kategori berada di posisi atas layar, nampak jelas dan menonjol sehingga memudahkan pengguna yang belum mempunyai judul buku yang hendak dicari untuk melakukan pencarian sesuai dengan kategori yang telah disediakan (Gambar 4).

Bagi sebuah toko buku yang memiliki ribuan koleksi buku, fitur pencarian seperti ini sangat penting bagi pengguna situs. Search bar dan menu utama kategori harus ditempatkan pada posisi yang mudah dilihat dan dijangkau oleh pengguna. Pada situs Gramedia, sudah mengakomodir fitur ini dengan baik, yaitu dengan menempatkan search bar pada posisi atas layar monitor.

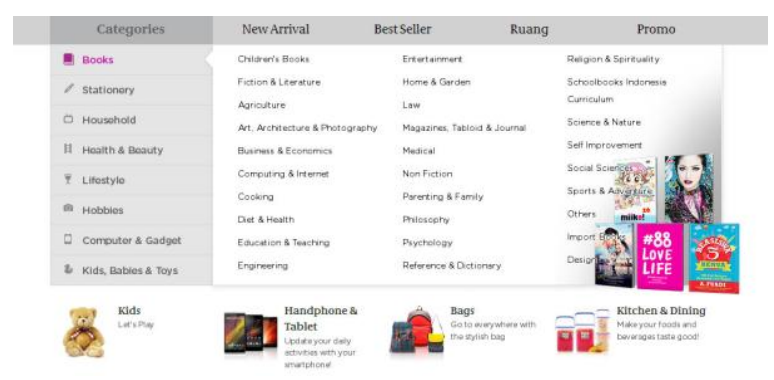

Gambar 4. Menu utama dan kategori

Terdapat 30 sub-kategori buku yang dapat dicari oleh pengguna website ini. Selain itu juga ada 8 kategori utama produk yang dijual oleh Gramedia, seperti: books, stationery, household, health \& beauty, lifestyle, hobbies, computer \& gadget, dan kids, babbes \& toys.

Ketiga, adanya section best seller dan new product pada halaman utama situs yang sengaja didesain untuk membantu pengguna mencari buku yang diinginkan (gambar 5). Penempatan elemenelemen ini jelas mempermudah pengguna untuk mencari dan memilih buku yang dikehendaki.

Pembagian section best seller dan new product ini sudah tepat. Adanya section ini membantu pengguna untuk melihat judul buku apakah yang banyak dibeli dan buku terbaru apa yang dimiliki oleh Toko Buku Gramedia.

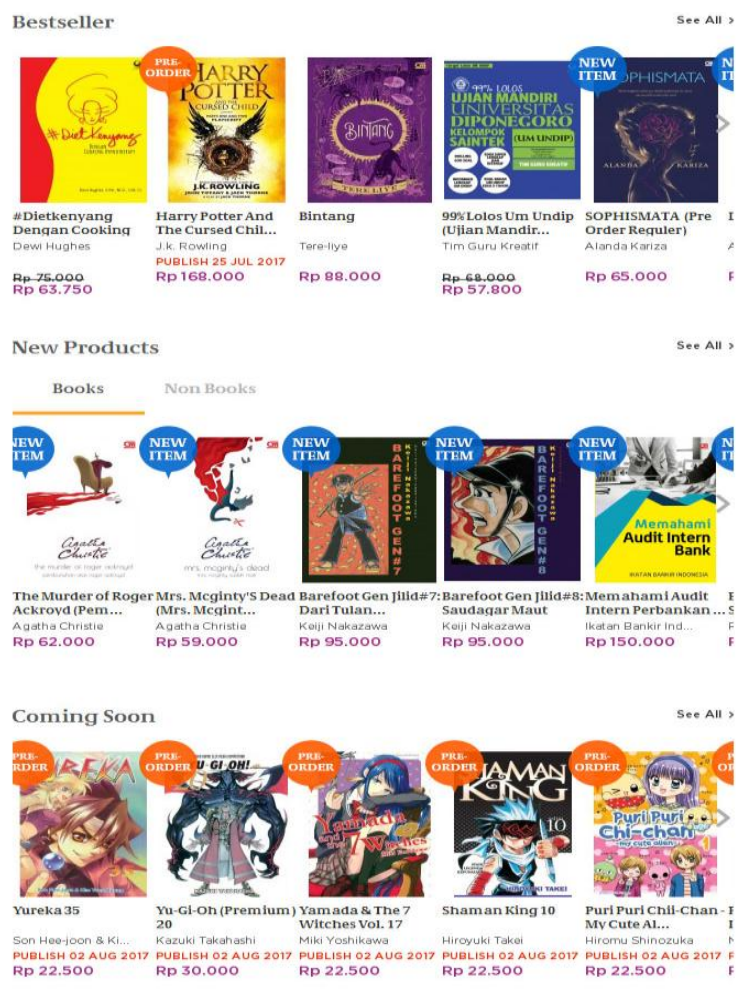

Gambar 5. Section Bestseller, new products, dan coming soon 
Selain fitur di atas, lazim ditemui dalam website ecommerce seperti ini adalah fitur login dan pembuatan akun. Dengan adanya fitur seperti ini, pengguna diwajibkan memberikan sejumlah data kepada pemilik website untuk kepentingan pengiriman dan pembayaran buku yang telah dibeli.

Sayangnya, bagi sebuah website e-commerce, situs Gramedia ini belum mendukung SSL Certificates. SSL Certificates adalah file data kecil yang secara digital mengikat kunci kriptografi ke detail organisasi. Saat diinstal pada server web, akan mengaktifkan gembok dan protokol HTTPS dan memungkinkan koneksi yang aman dari server web ke browser pengguna. Ada atau tidak adanya fitur ini bisa dideteksi dengan memeriksa ikon gembok atau tulisan "secure" pada url di browser. Padahal adanya fitur ini akan menambah keyakinan pengguna akan keamanan pada situs.

\section{Simpulan}

Dari contoh website Gramedia ini dapat dilihat bagaimana teknologi internet mampu mempengaruhi manusia. Pengaruh ini nampak dari interaksi manusia dan komputer melalui interface berkaitan dengan pembelian buku. Jika dahulu, membeli buku adalah dengan datang secara langsung ke toko buku, kini dapat dilakukan di mana saja dengan teknologi internet. Cukup dengan membuka website dari rumah, mencari judul secara langsung, dan melakukan pembayaran pada website.

Pola perubahan ini juga terkait dengan adaptasi dunia terhadap penambahan jumlah populasi manusia, di mana tentu saja memerlukan lahan yang lebih luas untuk bisa hidup dan berkembang. Namun tidak ada lahan lagi. Kemajuan teknologi menyebabkan adaptasi yang terjadi antara perkembangan manusia dan hidup (lingkungan) harus juga mampu beradaptasi dengan teknologi yang berkembang terus menerus dan desain membantu proses adaptasi ini.

Jika dilihat dari perkembangan antara manusia dengan jaman merupakan usaha untuk saling menyesuaikan diri untuk saling memenuhi dan terpenuhi berbagai kebutuhan yang ada. Toko buku online saat ini menjadi suatu solusi dari kebutuhan manusia yang semakin meninggi terhadap ilmu pengetahuan. Manusia menjadi semakin mudah dalam mendapatkan buku yang bisa didapat hanya dengan meng-klik berbagai fungsi yang ditawarkan pada website toko buku online. Mendapatkan buku yang diinginkan hanya dengan waktu yang singkat dengan tidak membuang waktu sehingga bisa dikerjakan dengan melakukan hal lainnya.

Hal ini tentunya dipandang sebagai sebuah unsur positif karena ada efisiensi waktu dan efektifitas lahan. Namun salah satu hal yang perlu diperhatikan adalah bahwa manusia modern memiliki kecenderungan menjadi manja dan bergantung terhadap kemudahan yang disediakan (ketergantungan yang sangat tinggi terhadap media).

Saat ini yang harus diperhatikan saat akan merancang website e-commerce bagi toko buku adalah menyediakan fitur pencarian. Fitur ini yang mendominasi user flow pada website, membantu pengguna menavigasi website dalam mencari buku-buku yang diinginkan. Perancangan sebuah website harus berbasis kepada pengguna (user), diharapkan jika perancang berorientasi pada pengguna maka pengalaman pengguna (UX) ketika menggunakan website akan membantu mereka lebih sering membeli melalui website.

Pada masa mendatang, media website seperti ini mungkin digantikan dengan media lainnya. Tren yang ada saat ini adalah berkaitan dengan virtual reality (VR). Bukan tidak mungkin suatu saat kita dapat berbelanja dari rumah namun seolah-olah merasakan belanja di dalam toko buku asli melalui media VR. Tapi untuk saat ini, media website masih menjadi alternatif penjualan melalui dunia virtual yang mudah dan menarik.

\section{Daftar Pustaka}

Flow Design Processes-Focusing on the User's Needs. (2017, July 1). Retrieved July 18, 2017, from Interaction Design Foundation: https://www.interaction-design.org/literature/ article/flow-design-processes-focusing-on-theuser-s-needs

GlobalSign. (2017). What is an SSL Certificates. Retrieved Juli 24, 2017, from GlobalSign: https://www.globalsign.com/en/ssl-information-center/what-is-an-ssl-certificate/

Lowdermilk, T. (2013). User-Centered Design. California, United States of America: O'Reilly.

Yayici, E. (2014). UX Design and Usability Mentor Book. United States of America: UX Service Inspiring Series. 